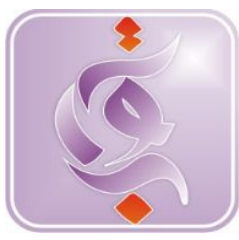

\title{
EKSPLORASI DIMENSI PSYCHOLOGICAL WELL-BEING MAHASISWA PSIKOLOGI ISLAM
}

\section{Rizal Kurniawan}

IAIN Imam Bonjol Padang

Email: rizal0kurniawan@gmail.com
Abstrak: Jurusan Psikologi Islam (PI) merupakan jurusan yang mengalami banyak tantangan. Hal tersebut akan berdampak pada kesejahteraan mahasiswa. Penelitian ini dilakukan untuk mengekplorasi bagaimana psychological wellbeing (PWB) atau kesejahteraan psikologis mahasiswa PI. Teori yang digunakan adalah dari Ryff (1987) yang menyatakan PWB terdiri dari enam dimensi. Situasi dirancang berdasarkan teori untuk melihat tingkat PWB mahasiswa untuk setiap dimensinya. Skala berbentuk semantik difrerensial digunakan untuk melihat tingkat kesulitan mahasiswa dalam merespon situasi tersebut. Sebanyak 193 orang mahasiswa PI ikut serta dalam penelitian ini dengan rata-rata umur 19 tahun. Sebagian besar mahasiswa PI dapat dengan mudah menghadapi situasi dari ke enam dimensi PWB. Dimensi yang paling sulit dihadapi oleh mahasiswa PI adalah tujuan hidup tertuma mahasiswa yang berada pada semester tiga dan lima. Mahasiswa PI mudah mencari kelebihan yang mereka miliki, namun kesulitan untuk mengembangkan potensi yang mereka miliki. Mahasiswa semester awal mengalami kesulitan dalam beradaptasi pada lingkungan tempat tinggal sendangkan semester tiga dan lima mengalami kesulitan dalam adaptasi lingkungan kampus. Mahasiswa PI juga merasa mudah untuk bercerita dengan teman namun mereka sulit untuk mempercayai teman mereka.

Kata kunci: Psychological well-being, Psikologi Islam<smiles>[PH]</smiles>
sikologi Islam merupakan salah satu jurusan yang relatif baru di Indonesia. Jurusan PI memiliki banyak tantangan oleh mahasiswanya. Seperti tidak diakui oleh HIMPSI, tidak diterima alumninya di beberapa universitas besar di Indo-nesia untuk menjadi mahasiswa magister profesi psikologi dan banyaknya kasus tidak diterimanya alumni mahasiswa PI untuk melamar kerja di instansi negeri. Dengan permasalahan tersebut akan berpe-ngaruh kepada kesejahteraan maha-siswa PI sendiri. Sehingga penting dilakukan penelitian untuk me-ngetahui keadaan kesejahteraan psikologis mahasiswa PI.

Kesejahteraan psikologis atau psychological well-being (PWB) merupakan salah satu konsep terbaru dalam kajian psikologi positif. PWB menawarkan sudut pandang baru dalam 
melihat kebahagiaan seseorang. Pendekatan sebelumnya lebih cenderung melihat kebahagiaan secara subjektif seperti konsep happiness dan subjective well-being (SWB). Pendekatan ini lebih melihat kebahagiaan dengan hadirnya afeksi yang positif dan tidak adanya afeksi negatif yang dirasakan oleh seseorang. Sedangkan PWB lebih melihat kebahagian dari pengalaman kehidupan seseorang (Deci, E. L., \& Ryan, R. M, 2008).

Eksplorasi PWB pada mahasiswa PI sudah dilakukan oleh Kurniawan (2015) yang melakukan menggunakan pendekatan pemodelan Rasch untuk eksplorasi PWB mereka. Hasilnya menyatakan bahwa sebaigan besar mahasiswa PI memiliki tingkat PWB yang tinggi. Kelemahan dari penelitian ini adalah eksplorasi yang dilakukan tidak terlalu detail. Penelitian ini hanya melakukan eksplorasi berdasarkan dimensi PWB saja. Penelitian ini belum melakukan eksplorasi setiap dimensi PWB berdasarkan tingkat semesternya mahasiswanya. Asumsinya adalah setiap semester mahasiswa memiliki kemampuan berbeda di dalam menjalani pengalamanpengalamannya. Misalnya semester 5 lebih terampil dalam menguasai lingkungan dibandingkan dengan mahasiswa dari semester 1 karena mereka telah berada di lingkungan kampus lebih lama. Penelitian ini dilakukan untuk melanjutkan penelitian Kurniawan (2015) dalam mengekplorasi lebih jauh lagi dimensi PWB.

Teori PWB dikembangkan oleh Menurut Ryff (1989) yang menyatakan terdapat enam dimensi untuk melihat tingkat PWB seseorang. Dimensi PWB terdiri dari penerimaan diri, pribadi yang berkembang, tujuan hidup, penguasaan lingkungan, autonomi dan relasi yang positif. Penerimaan diri adalah seberapa besar seseorang mampu menerima kebaikan dan keburukan dirinya, misalnya menerima kelebihan dan kekurangan diri. Pengembangan pribadi merupakan gambaran tentang bagaimana seseorang memiliki keinginan untuk berkembang menjadi lebih baik, seperti senang mempelajari sesuatu yang baru. Tujuan hidup adalah varibel yang mengambarkan seorang yang sejahtera adalah mereka yang memiliki tujuan hidup yang jelas dan mampu belajar dari masa lalu. Penguasaan lingkungan merupakan ciri kesejahteraan seseorang yang berkaitan dengan kamampuan seseorang dalam berelasi dengan lingkungannya, seperti mudah diterima oleh orang lain. Autonom berarti tidak terikat dengan sesuatu, misalnya mampu mengambil keputusan sendiri. Relasi yang positif adalah ciri dari kesejahteraan yang menggambarkan bahwa seseorang harus mampu mengembangkan relasi yang baik dengan orang lain, misalnya menjalin persahabatan (Snyder \& Lopez, 2007, Kurniawan, 2015) .

\section{Pemodelan Rasch}

Pemodelan Rasch merupakan suatu pendekatan modern di dalam kajian psikometri. Skor yang didapatkan oleh responden di dalam pendekatan ini akan dikonversikan ke dalam logit (log odd units). Nilai logit telah berbentuk interval. Perbedaan utama pemodelan Rasch dengan pendekatan klasik adalah terdapatnya tingkat kesulitan pada aitem skala. Semakin tinggi nilai logit dari suatu aitem semakin sulit pula aitem tersebut untuk disetujui oleh responden. Dengan perkataan lain, aitem tersebut hanya mampu disetejui oleh responden yang memiliki abilitas yang tinggi saja. Aitem yang memiliki nilai logit sebesar 0 memiliki tingkat kesulitan sedang untuk disetujui (Bond \& Fox, 2007; Sumintono, \& Widhiarso, 2014; Wilson, 2005).

Selain nilai logit aitem, pendekatan pemodelan Rasch juga menghasilkan nilai logit untuk responden. Nilai logit untuk responden mengambarkan tingkat abilitas dari responden tersebut, dalam penelitian ini adalah dimensi-dimensi PWB yang terdiri dari penerimaan diri, pengembangan pribadi, tujuan hidup, penguasaan 
lingkungan, autonom dan relasi positif. Abilitas merupakan istilah umum yang mengambarkan trait seseorang. Abilitas akan berubah berdasarkan objek ukurnya, misalnya dalam pengukuran kecemasan abilitas diinterpretasikan sebagai kecemasan. Semakin tinggi nilai logit responden semakin tinggi abilitas yang dia miliki dan sebaliknya. Nilai logit sebesar 0 pada responden menunjukkan responden tersebut memiliki tingkat abilitas yang sedang (Bond \& Fox, 2007). Untuk mempermudah perhitungan, penelitian ini menggunakan software winsteps versi 3.73.

\section{METODE}

Instrumen penelitian

Instrumen yang digunakan pada penelitian ini adalah skala psikologis. Skala psikologi terdiri dari aitem-aitem yang dibuat dalam bentuk kondisi-kondisi tertentu yang diasumsikan sering dihadapi oleh mahasiswa dalam kegiatan harian mereka. Kondisi tersebut dibuat berdasarkan teori PWB dari Ryff (1989). Mahasiswa harus merespon kondisikondisi yang ada di dalam skala tersebut. Respon yang digunakan pada skala adalah semantik diferensial. Responden merespon kondisi berdasarkan kemudahan yang dirasakan oleh responden ketika menghadapi situasi tersebut. Semakin tinggi skor yang didapatkan maka semakin mudah pula responden tersebut menghadapi kondisi yang ada. Dimensi yang dikemukakan oleh Ryff (1989) menyatakan bahwa PWB terdiri dari enam dimensi. Kondisi yang dibuat berdasarkan ke enam dimensi tersebut. Setiap dimensi diwakili oleh 5 aitem yang harus direspon. Secara lengkap instrumen penelitian ini dapat dilihat pada tabel. 1 .

Tabel. 1 Instrumen Penelitian

\begin{tabular}{|c|c|}
\hline \multicolumn{1}{|c|}{ Aitem } & Respond \\
\hline Penerimaan diri & \\
\hline
\end{tabular}

Rizal, Eksplorasi Dimensi Psychological...

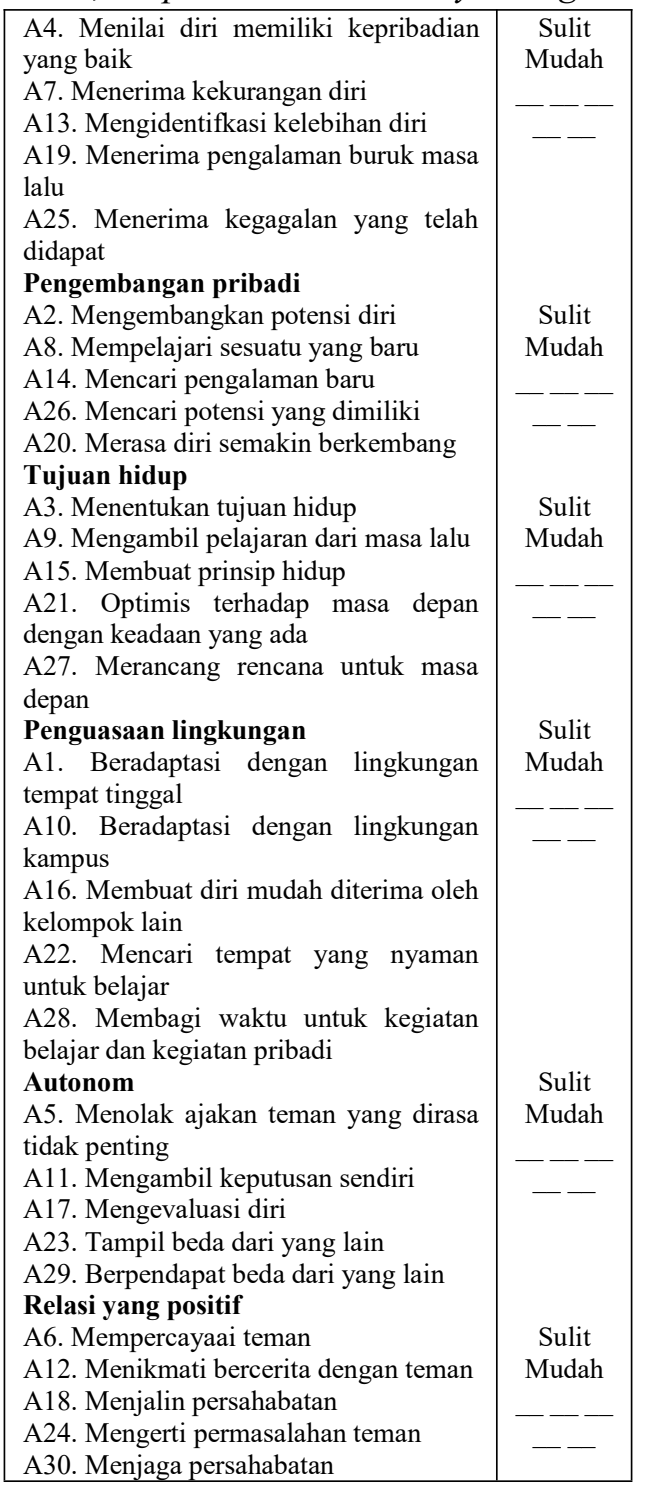

Subjek penelitian

Sebanyak 193 orang mahasiswa Psikologi Islam ikut berpartisipasi pada penelitian ini. Subjek penelitian terdiri dari 33 orang laki-laki dan 193 orang perempuan. Rerata umur subjek adalah 19 tahun. Subjek penelitian paling muda berumur 17 tahun dan paling tua berumur 23 tahun. Mahasiswa semester satu dilibatkan sebanyak 50 orang, semester tiga 73 orang dan semester lima 70 orang.

\section{HASIL DAN PEMBAHASAN Hasil}

Hasil estimasi dengan menggunakan pendekatan Rasch di dapatkan hasil seperti pada tabel. 2. Dari Tabel tersebu kita dapat melihat bahwa sebagian besar nilai mean logit setiap 
semester berdasarkan dimensi PWB memiliki nilai yang positif, kecuali untuk dimensi tujuan hidup pada semester tiga dan semester lima. Logit yang positif menunjukkan bahwa responden merasa mudah dalam menghadapi situasi-situasi yang ada pada aitem dan sebaliknya.

Tabel. 2 Hasil Estimasi Nilai Logit Dimensi PWB berdasarkan Semester

\begin{tabular}{|l|c|c|c|c|}
\hline \multicolumn{1}{|c|}{$\begin{array}{c}\text { Dimensi } \\
\text { PWB }\end{array}$} & $\begin{array}{c}\text { Sem } \\
\text { ester } \\
1\end{array}$ & $\begin{array}{c}\text { Sem } \\
\text { ester } \\
3\end{array}$ & $\begin{array}{c}\text { Sem } \\
\text { ester } \\
5\end{array}$ & Ket \\
\hline $\begin{array}{l}\text { Penerimaan } \\
\text { diri }\end{array}$ & 0,44 & 0,22 & 0,43 & $\begin{array}{c}\text { Tidak } \\
\text { signifika } \\
\mathrm{n}\end{array}$ \\
\hline $\begin{array}{l}\text { Pribadi yang } \\
\text { berkembang }\end{array}$ & 0,45 & 0,33 & 0,72 & $\begin{array}{c}1=3< \\
5\end{array}$ \\
\hline $\begin{array}{l}\text { Tujuan } \\
\text { hidup }\end{array}$ & 0,12 & - & - & $\begin{array}{c}\text { Tidak } \\
\text { signifika } \\
\mathrm{n}\end{array}$ \\
\hline $\begin{array}{l}\text { Penguasaan } \\
\text { lingkungan }\end{array}$ & 0,11 & 0,09 & 0,81 & $\begin{array}{c}1=3< \\
5\end{array}$ \\
\hline Autonomi & 0,23 & 0,42 & 0,54 & $\begin{array}{c}3=1< \\
5\end{array}$ \\
\hline $\begin{array}{l}\text { Relasi } \\
\text { positif }\end{array}$ & 0,94 & 0,78 & 0,74 & $\begin{array}{c}\text { Tidak } \\
\text { signifika } \\
\mathrm{n}\end{array}$ \\
\hline
\end{tabular}

Dari hasil yang didapatkan menunjukkan ada perbedaan logit dimensi PWB berdasarkan semester. Dimensi penerimaan diri, tujuan hidup dan relasi yang positif tidak menunjukkan perbedaan logit beradasarkan semester. Artinya kemampuan responden dalam meng-hadapi situasi untuk setiap dimensi PWB adalah sama.

Dimensi pribadi yang berkembang menunjukkan terdapat perbedaan beradasarkan semester. Di mana semester lima memiliki perkembangan pribadi yang baik dibandingkan semester tiga namun tidak signifikan dengan semester satu. Hasil yang menarik di sini adalah semester tiga memiliki perkembangan pribadi yang paling rendah. Artinya perkembangan pribadi yang baik ketika mereka berada di semester lima. Ketika mahasiswa semester tiga belum menunjukkan perkembangan pribadi yang signifikan, bahkan pada hasil penelitian ini menunjukkan perkembangan pribadi yang paling rendah.

Dimensi penguasaan lingkungan menunjukkan hasil yang sama dengan perkembangan pribadi. Semester lima memiliki kemampuan penguasaan lingkungan yang baik dibandingkan dengan semester satu dan semester tiga. Kemampuan penguasaan lingkungan antara semester satu dan tiga tidak signifikan, artinya kemampuan penguasaan lingkungan antara ke duanya adalah sama. Artinya, kemampuan penguasaan lingkungan pada mahasiswa PI akan terlihat ketika mereka semester berada di semester lima.

Dimensi autonomi yang baik juga ditunjukkan mahasiswa semester lima. Perasaan autonomi akan lebih baik ketika mahasiswa berada pada semester lima. Semester satu memiliki nilai logit paling rendah namun tidak berbeda secara signifikan dengan nilai logit semester tiga. Artinya mahasiswa yang baru masuk kuliah merasa outonomi yang rendah dan akan meningkat seiring meningkatnya semester mahasiswa tersebut.

\section{Perbandingan Dimensi PWB Berdasarkan Semester}

Hasil estimasi aitem untuk setiap dimensi PWB dapat dilihat pada tabel. 3. Pada dimensi pene-rimaan diri mahasiswa yang berada pada semester satu, tiga dan lima paling mudah menghadapi situasi pada nomor 13 (Mengidentifikasi kelebihan diri). Untuk situasi yang sulit dihadapi, setiap semester menunjukkan hasil yang berbeda. Semester satu sulit menghadapi situasi pada nomor 19 (Menerima pengalaman buruk masa lalu). Semester dua sulit dalam meng-hadapi situasi pada nomor 4 (Menilai diri memiliki kepribadian yang baik). Sedangkan mahasiswa yang berada pada semester lima mengalami kesulitan dalam menghadapi situasi pada nomor 25 (Menerima kegagalan yang telah didapatkan). Untuk situasi pada nomor 4 (Menilai diri memiliki kepribadian yang baik) cenderung dirasakan sulit oleh mahasiswa yang berada pada semester satu dan semester tiga. Situasi yang sama 
dirasakan mudah oleh mereka yang berada di semester lima. Situasi pada nomor 19 (Menerima pengalaman buruk masa lalu) dirasakan sulit oleh mahasiswa semester satu dan tiga. Kodisi yang sama dirasakan mudah oleh semester lima.

Mahasiswa pada semester satu, dua dan tiga memiliki kesulitan yang sama dalam menghadapi situasi pada dimensi pribadi yang ber-kembang. Baik pada semester satu, dua maupun tiga sama-sama ke-sulitan dalam menghadapi situasi yang berada pada nomor 2 (Me-ngembangkan potensi diri). Situasi yang paling mudah dihadapi oleh bagi mereka adalah situasi pada nomor 20 (Merasakan diri semakin berkembang). Pada situasi nomor 26 (Mencari potensi yang dimiliki) se-mester satu merasa sulit untuk meng-hadapinya, dan situasi ini dirasakan mudah oleh mereka yang berada pada semester 3 dan semester 5 .

Pada dimensi tujuan hidup, mahasiswa pada setiap semester mengalami kesulitan dalam meng-hadapi situasi pada nomor 3 (Menentukan tujuan hidup). Situasi yang mudah untuk mereka hadapi pada dimensi ini adalah situasi pada nomor 21 (Optimis terhadap masa depan dengan keadaan yang ada). Situasi dengan nomor 9 (Mengambil pelajaran dari masa lalu) dirasakan mudah mahasiswa yang berada pada semester 1 dan semester 5 . Justru mereka yang berada pada semester tiga merasa sulit menghadapi situasi nomor 9 ini. Situasi nomor 15 (Mem-buat prinsip hidup) dirasakan mudah oleh mereka yang berada pada semester 5 dan dirasakan sulit oleh mereka yang berada pada semester satu dan semester tiga. Situasi pada nomor 27 (Merancang rencana untuk masa depan) dirasakan sulit oleh mereka yang berada di semester satu dan dirasakan mudah oleh mereka yang berada pada semester tiga dan lima.

Situasi pada dimensi pe-nguasaan lingkungan semua maha-siswa yang berada di semester satu, tiga maupun lima merasakan mudah dalam menghadapi situasi pada nomor 16 (Membuat diri
Rizal, Eksplorasi Dimensi Psychological... 85 mudah diterima oleh kelompok lain). Situasi yang dirasakan sulit pada semester satu adalah situasi pada nomor 1 (Beradaptasi dengan lingkungan tempat tinggal). Sedangkan situasi yang dirasakan sulit oleh mahasiswa semester tiga dan lima adalah sama yaitu situasi yang berada pada nomor 10 (Beradaptasi dengan lingkungan kampus).

Pada dimensi autonomi mahasiswa semester satu dan tiga paling mudah dalam menghadapi situasi pada nomor 11 (Mengambil keputusan sendiri). Sedangkan mahasiswa yang berada pada semester lima paling mudah dalam mengadapi situasi pada nomor 29 (Berpendapat berbeda dari yang lain). Situasi yang dirasakan sulit oleh mahasiswa semester satu adalah situasi yang berada pada nomor 23 (Tampil beda dari yang lain). Sedangkan situasi yang sulit bagi mereka yang berada pada semester tiga dan lima adalah situasi yang berada pada nomor 17 (Mengevaluasi diri).

Tabel.3 Hasil estimasi aitem dimensi PWB berdasarkan semester.

\begin{tabular}{|c|c|c|c|c|}
\hline \multirow{3}{*}{ Dimensi } & \multirow{2}{*}{$\begin{array}{c}\text { Aite } \\
\mathrm{m}\end{array}$} & $\begin{array}{c}\text { Semes } \\
\text { ter 1 }\end{array}$ & $\begin{array}{c}\text { Semes } \\
\text { ter 2 }\end{array}$ & $\begin{array}{c}\text { Semes } \\
\text { ter 3 }\end{array}$ \\
\cline { 3 - 5 } & & Mean & Mean & Mean \\
\hline
\end{tabular}




\begin{tabular}{|l|c|c|c|c|}
\hline & & logit & logit & logit \\
\hline Penerima & A4 & 0,14 & 0,32 & $-0,08$ \\
an diri & A7 & $-0,17$ & $-0,07$ & $-0,01$ \\
& A13 & $-0,29$ & $-0,56$ & $-0,45$ \\
& A19 & 0,19 & 0,07 & $-0,06$ \\
& A25 & 0,12 & 0,24 & 0,60 \\
\hline Pribadi & A2 & 0,44 & 0,47 & 0,47 \\
yang & A8 & 0,01 & 0,45 & 0,42 \\
berkemb & A14 & 0,11 & 0,09 & 0,29 \\
ang & A26 & 0,12 & $-0,10$ & $-0,21$ \\
& A20 & $-0,67$ & $-0,91$ & $-0,97$ \\
\hline Tujuan & A3 & 0,25 & 0,26 & 0,59 \\
hidup & A9 & $-0,01$ & 0,14 & $-0,30$ \\
& A15 & $-0,07$ & $-0,11$ & 0,27 \\
& A21 & $-0,19$ & $-0,19$ & $-0,41$ \\
& A27 & 0,02 & $-0,10$ & $-0,15$ \\
\hline Penguasa & A1 & 0,78 & 0,19 & 0,27 \\
an & A10 & 0,30 & 0,46 & 0,33 \\
lingkung & A16 & $-0,85$ & $-0,61$ & $-0,41$ \\
an & A22 & $-0,28$ & $-0,04$ & $-0,25$ \\
& A28 & 0,05 & 0,00 & 0,07 \\
\hline Autonomi & A5 & 0,09 & $-0,16$ & 0,08 \\
& A11 & $-0,31$ & $-0,31$ & 0,00 \\
& A17 & 0,02 & 0,25 & 0,30 \\
& A23 & 0,23 & 0,12 & $-0,15$ \\
& A29 & $-0,05$ & 0,09 & $-0,23$ \\
\hline Relasi & A6 & 1.11 & 0,63 & 1,36 \\
positif & A12 & -0.50 & $-0,27$ & $-0,66$ \\
& A18 & 0.16 & 0,13 & 0,17 \\
& A24 & $-0,50$ & $-0,27$ & $-0,64$ \\
& A30 & $-0,28$ & $-0,21$ & $-0,22$ \\
\hline
\end{tabular}

Situasi nomor 5 untuk dimensi autonomi (Menolak ajakan teman untuk kegiatan yang dirasa tidak penting) dirasakan sulit untuk mereka yang berada pada semester satu dan semester lima. Situasi yang sama dirasakan mudah oleh mahasiswa semester tiga. Situasi yang berada pada nomor 11 (Mengambil keputusan sendiri) dirasakan sulit oleh mereka yang berada pada semester satu dan tiga. Situasi yang sama dirasakan mudah oleh semester lima. Pada situasi nomor 29 (Berpendapat berbeda dari yang lain) dirasakan mudah bagi mereka yang berada pada semester satu dan lima dan dirasakan sulit bagi mahasiswa semester tiga.

Situasi yang paling mudah untuk dihadapi oleh mahasiswa semester satu, tiga dan lima pada dimensi relasi positif adalah situasi dengan nomor 12 (Menikmati bercerita dengan teman).
Sedangkan situasi yang paling sulit untuk dihadapi oleh semester satu, tiga dan lima adalah situasi pada nomor 6 (Mempercayaai teman).

\section{PEMBAHASAN}

Hasil yang menarik pada tabel. 2 ditunjukkan oleh dimensi tujuan hidup. Dari nilai logit dimensi-dimensi PWB yang ada dimensi tujuan hidup yang paling rendah baik pada semester satu, semester tiga maupun semester lima. Bahkan semester tiga dan semester lima memiliki nilai logit rata-rata yang negatif. Artinya mahasiswa merasa sulit dalam menghadapi situasi yang berkaitan dengan tujuan hidup. Masalah jurusan yang ada di dalam PI dapat menyebabkan terjadinya hal ini. Mahasiswa baru masuk yang memiliki cita-cita ingin sukses ketika kuliah di jurusan PI dan mengetahui masalahmasalah yang ada di jurusan menyebabkan tujuan hidupnya menjadi kacau. Hal ini terus dikembangkan pada semestersemester selanjutnya. Hasil penelitian ini menunjukkan bahwa semester tiga dan lima memiliki tujuan hidup yang masih belum jelas. Hal ini dibuktikan mereka kesulitan ketika menghadapi situasi yang berkaitan dengan tujuan hidup.

Penerimaan diri mahasiswa PI lebih dilakukan dengan cara mengidentifikasi kelebihan yang mereka miliki. Kelebihan yang telah teridentifikasi mereka salurkan melalui organisasi kampus. Pendapat ini didukung dengan data bahwa hampir setengah dari mahasiswa (48\%) bergabung dengan organisasi kampus maupun organisasi non kampus. Dari hasil penelitian Kurniawan (2015) juga menyatakan organisasi merupakan sarana yang baik untuk meningkatkan penerimaan diri mahasiswa. Hal ini juga didukung beradasarkan hasil diskusi dengan para alumni PI yang menyatakan bahwa sebagian mereka yang bekerja dikarenakan penga-laman berorganisasi yang mereka ikuti. Ijazah Psikologi Islam sebagian besar 
tidak diterima untuk instansi-instansi negeri.

Situasi yang menarik untuk semua mahasiswa PI baik mereka berada di semester satu, tiga maupun lima adalah mereka merasa kesulitan untuk mengembangkan potensi yang mereka miliki, namun pada sisi lain justru mereka mudah untuk merasakan diri mereka semakin berkembang. Situasi ini merupakan sebuah ide menarik untuk kajian selanjutnya. Mengapa mahasiswa PI yang sulit mengembangkan potensi mereka justru mereka merasa semakin berkembang. Berkembang di bidang apakah yang mereka rasakan? Merupakan pertanyaan yang menarik untuk dijawab.

Pada dimensi tujuan hidup mahasiswa mengalami kesulitan dalam menentukan tujuan hidup mereka. Namun yang menarik di sini adalah mereka mempunyai rasa optimis yang tinggi. Walaupun dengan masalah kampus yang mereka rasakan, mereka tetap merasa optimis dengan masa depan mereka.

Dimensi penguasaan lingkungan menghasilkan bahwa mereka yang berada pada semester satu situasi yang paling sulit untuk dihadapi adalah adaptasi tempat tinggal. Hal ini wajar karena sebagian besar mereka baru menempati kos pada lingkungan baru sehingga masih berusaha beradaptasi dengan tempat tinggal mereka. Yang menarik justru dimensi penguasaan lingkungan yang dirasakan sulit oleh semester tiga dan lima adalah adaptasi dengan kampus. Artinya terdapat masalah dengan situasi kampus seperti sarana belajar siswa, tempat duduk siswa, ketersediaan wifi dan sebagainya .

Hal menarik juga muncul dari relasi mahasiswa PI. Mereka sangat mudah menikmati berbicara dengan teman. Namum juga mereka sangat sulit untuk mempercayai teman mereka sendiri. Hal ini juga menarik untuk diteliti lebih lanjut bagaimana relasi mahasiswa PI dengan teman mereka.

\section{SIMPULAN}

Dari hasil estimasi yang dilakukan dapat disimpulkan bahwa sebagian besar mahasiswa memiliki kemampuan untuk meghadapi ke enam dimensi dari PWB. Situasi yang paling sulit dihadapi oleh mahasiswa adalah tujuan hidup terutama mereka yang berada pada semester tiga dan lima. Penerimaan diri mahasiswa dilakukan dengan cara menemukan kelebihan yang ada pada diri mereka. Mahasiswa PI me-ngalami kesulitan dalam mengem-bangkan potensi diri namun mereka memiliki optimisme yang baik. Mahasiswa semester satu mengalami kesulitan dalam beradaptasi dengan lingkugannya sedangkan semester tiga dan lima mengalami kesulitan dalam adaptasi kampus. Mahasiswa PI mudah menikmati bercerita dengan teman, namun mereka sulit untuk percaya terhadap teman mereka.

\section{DAFTAR RUJUKAN}

Bond, T. G., \& Fox, C. M. 2007. Applying The Rasch Model: Fundamental Measurement in The Human Science. Second edition. New Jersey: Lawrence Erlbaum.

Deci, E. L., \& Ryan, R. M. 2008. Hedonia, Eudaimonia and well-being: An Introduction. Journal of Happiness Studies. 9, 1-11.

Kurniawan. R. 2015. Apakah mahasiswa Psikologi Islam bahagia?: Gambaran psycological well-being pada mahasiswa Psikologi Islam Fakultas Ushuluddin IAIN Imam Bonjol Padang dengan pendekatan pemodelan Rasch. Konsorsium Keilmuan Psikologi Islam seIndonesia.

Ryff, C. D. 1989. Happiness of everything, or is it? Exploration of the meaning of psychological well-being. Journal of Personality and Social Psychology, 57, 1069-1081.

Snyder, C. R \& Lopez, S. J. 2007. Positive Psychology: The Scientific and 
88 Jurnal Al-Qalb, Jilid 7, Nomor 2, September 2015, hlm. 81-88

Practical Exploration of Human Strengths. California: Sage.

Sumintono, B., \& Widhiarso, W. 2014. Aplikasi Model Rasch Untuk Penelitian Ilmu-ilmu Sosial (Edisi
Revisi). Bandung: Trim Komunikata.

Wilson, M. 2005. Constructing Measures: An Item Response Modeling Approach. New Jersey. Lawrence Erlbaum. 